\title{
Monetary Programming in Albania
}

\author{
Dr. Fiqiri Baholli \\ Lecturer in the Faculty of Economy and Agribusiness (AU Tirana) \\ Email: fbaholli@yahoo.com

\section{Dr. Fehmi Azemi}

PHD in the Economy and Agribusiness (Agricultural University Tirana)

Email: fehmi.azemi@gmail.com

\section{Doi:10.5901/ajis.2016.v5n3s1p171}

\begin{abstract}
The development of every country is supported in formulation and implementation of macroeconomic program. Policies are formulated to correct disequilibrium between aggregate supply and demand, misbalances shown in the balance of payments, price increase and low increase of national product. An important part of this process is monetary programming as a main duty for the Bank of Albania. The object of this article is to prove the indicator that can be easily monitored to follow up the operational actions of the Bank of Albania aiming the achievement of main objective. On the economic analysis presented on this article we explain if the monetary aggregates could be used as operational objectives. Friedman (1998) suggests that timing and relations with main objectives are key elements for monetary aggregates. McCallum (1999) that the identification of monetary aggregates is added value on the framework of monetary policy formulation. Econometric analysis consists on the models realized to explain and test the relations of the monetary aggregates with macroeconomic indicators. Models are drafted based on three hypothesis. Other objectives of this study are related to brief analyses on the monetary policies compiled and realized from the Bank of Albania. Also through regression analysis we will show the relations of monetary aggregates and their impact on macroeconomic indicators, such as Gross Domestic Product and Consumer Prices Index.
\end{abstract}

Keywords: monetary aggregates, Gross Domestic Product (GDP), inflation.

\section{Objectives of the Study}

Increasing the GDP and lowering inflation rates has proved to direct most of the developed and less developed economies toward sustainable strengthening of economic growth. Price stability is the main objective of almost all central banks on monetary conditions that are support this growth.The Bank of Albania follows, in short term, main and intermediary objectives in order to achieve its final objective - price stability - which is set on longer term.

During last 25 years Albania had two periods with high inflation rate with two digits, while since 2007 the inflation level is stabilized to around 3 percent. Inflation is measured with consumers price for a basket of articles that represent family consumption on goods and services.

Monetary programming as important part of financial programming is an important tool used on economic forecasting (ex ante) aiming to give reference levels and control points for policymakers. General orientation given from International Monetary Fund, Bank for International Settlements in Basel and other international organizations are applied considering differences on the financial system of each country - including transition economies.

The framework of monetary programming includes and is realized through:

- Main objectives (inflation control, economic growth, stable Balance of Payments);

- Intermediary targets (growth of money supply);

- Operational benchmarks (reserve money) controlled with monetary policy instruments.

This study aims to give contribution on the continuous refining on the use of monetary programming of the Bank of Albania. Main objective of the study is to prove, which is the best indicator that should be monitored to control the operations of central bank. These operations are organized to ensure the financial stability of the country and the achievement of its main objective - price stability.

Other objectives of this study are related to brief analyses on the monetary policies compiled and realized from the Bank of Albania. Also through regression analysis we will show the relations of monetary aggregates and their impact on macroeconomic indicators, such as Gross Domestic Product and Consumer Prices Index. 


\section{Hypothesis and Research Questions}

Econometric analysis consists on the models realized to explain and test the relations of the monetary aggregates with macroeconomic indicators. Models are drafted based on three hypothesis(assumptions).

First: the relative change of aggregate M1, M2 and M3 are depended on the relative changes of GDP and Inflation.

Second: Absolute changes of M1, M2 and M3 are depended on the absolute changes of GDP and Inflation.

Third: The level of monetary aggregates is depended from the level of GDP and inflation for the same time period.

\section{Methodology, Models and Data Analysis}

On the economic analysis presented on this paper we explain if the monetary aggregates could be used as operational objectives. Friedman (1998) suggests that timing and relations with main objectives are key elements for monetary aggregates. McCallum (1999) that the identification of monetary aggregates is added value on the framework of monetary policy formulation. The information used in this article includes 80 quarterly observations from $1^{\text {st }}$ quarter of 1995 till $4^{\text {th }}$ quarter 2014.

The Gross Domestic Product is not measured officially on quarterly bases. The estimations of International Monetary Fund and statistics published from the Institute of Statistics - INSTAT.

Official rate of inflation in Albania is measured on monthly and annual basis with the Consumer Price Index from INSTAT. The inflation target is published from the Bank of Albania and quarterly level is calculated as average of monthly indexes.

Monetary aggregates in Albania are:

M1 = Currency Outside the Banks + Demand Deposits in ALL

$\mathrm{M} 2=\mathrm{M} 1+$ Time and Savings deposits in ALL

M3 = M2 + Time and Demand Deposits in Foreign Exchange.

The indicators performance is graphically presented on the levels given each quarter from Q1-1995 till Q4- 2014 (80 observations).

The compilation of monetary program involves a lot of preparatory work that includes the recent development of main sectors of an economy: fiscal, monetary, real and relations with other countries. Institutions that prepare and publish the statistics of our economy are:

- The Bank of Albania for monetary sector and the balance of payments,

- The Ministry of Finance for fiscal sector and accounts of government,

- The Institute of Statistics (INSTAT) for real sector.

Most of the information for real sector is prepared also in other ministries or public entities. As mentioned the real sector statistics have problems, while institutional coordination is not yet in good basis.

The indicators of monetary program are economic or financial variables that help the central bank to assess economic conditions and to project future inflation. Indicators are an important element in policy making because inform the central bank on actual economic conditions and necessitate for corrective actions.

One of the problems on the assessment of macroeconomic relations in Albania is the lack of information (or incorrect data), especially in national account statistics.

The determination of proper role for monetary aggregates is an important issue for the Bank of Albania in the context of inflation targeting strategy. Several studies on this role deal with experiences of other central banks in policymaking in order to prove the relations between aggregates and inflation.

The econometric models are treated as an instrument that examines the link among money ( monetary aggregates) prices and gross domestic product.

Hallman $(1989,1991)$ presented a linear regression model based on the quantitative theory of money that determines long term price equilibrium. This model was presented for big economies with independent monetary policy. In $1994 \mathrm{Kool}$ and Tatoon adopted models for small economies with fixed foreign exchange regimes.

On the econometric analyses presented in this paper the monetary aggregates will be considered as prospective objectives for the Bank of Albania operations. Friedman highlights in 1998 that time and relations with final objectives are key elements for monetary indicators. Mc Callum (1999) suggests that identification and use of monetary aggregates are value added to the monetary policy formulation criteria.

The performance of indicators is presented in graphs with growth level counted as observed quarters - first quarter of 1995 written as number one, while number 80 is the last quarter of 2014. 
- Gross Domestic Product (G) graph shows a uniform growing trend, reflecting counting and reporting problems mentioned earlier.

- Inflation (I) graph shows fluctuations mostly due to the fall of pyramid schemes during 1998 - 1999,

- M1 graph shows seasonal and monetary balance movements of currency in circulation and demand deposits of commercial banks,

M2 and M3 graphs show the stable growing tendency of deposits in the banking system.
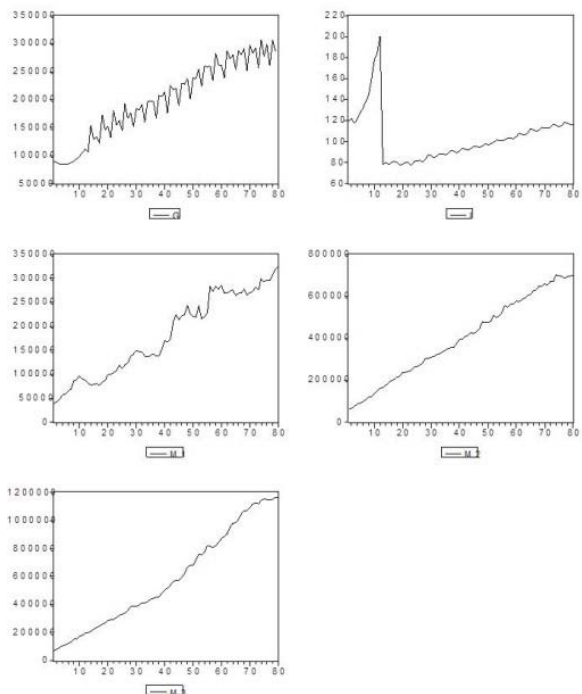

Graph 1. Levels of GDP, Inflation, M1, M2, M3 Aggregates

Source: Bank of Albania statistics for indicators of GDP, Inflation, M1,M2,M3 Aggregates

The methods used are:

- Statistics for average and graphs

- Econometric modeling with e-views

The econometric analysis consists on the models prepared to explain and test the relations of monetary aggregates with macroeconomic indicators (GDP and Inflation).

\subsection{To test first hypothesis are prepared model for M1}

Dependent Variable: LOG(M1)

Method: Least Squares

Sample(adjusted): 179

Included observations: 79 after adjusting endpoints

\begin{tabular}{lcllc}
\hline \multicolumn{1}{c}{ Variable } & Coefficient & \multicolumn{1}{c}{ Std. Error } & t-Statistic & Prob. \\
\hline \hline C & -7.433870 & 0.748608 & -9.930261 & 0.0000 \\
LOG(G) & 1.403620 & 0.045759 & 30.67419 & 0.0000 \\
\hline \hline R-squared & 0.510230 & 0.087909 & 5.804069 & 0.0000 \\
Adjusted R-squared & 0.925264 & Mean dependent var & 11.95708 \\
S.E. of regression & 0.923298 & S.D. dependent var & 0.558436 \\
Sum squared resid & 0.154660 & Akaike info criterion & -0.857941 \\
Log likelihood & 1.817898 & Schëarz criterion & -0.767962 \\
Durbin-Ëatson stat & 36.88866 & F-statistic & 470.4591 \\
\hline \hline
\end{tabular}


Model:

\section{LOG(M1) = -7,43387 + 1,40362* LOG(G) + 0,51023* LOG(I)+e}

Model for M1 passes the basis tests. The parameters are important as it is shown from propability (less than 0,05 ). In general the model is significant. Almost $93 \%$ on the variance of relative change in M1 is defined from relative change of $\mathrm{G}$ and $\mathrm{I}$. The diference is defined from other random or unconsidered factors. The model with relative change of $\mathrm{M} 1$ verifies that for every percentage unit increase of $\mathrm{G}$, there is $1,4 \%$ unit increase in $\mathrm{M} 1$, while for $1 \%$ increase of inflation is expected to be $0,5 \%$ increase on M1.

\subsection{The second hypothesis}

The focus for this hypothesis are the absolute changes of aggregates from one quarter to the other, given as D(M1). Factors that affect on absolute addition of dependent variables are considered:

- Absolute addition (change) of Inflation $D(I)$ and

- Absolute addition (change) of Gross Domestic Product $D(G)$ on the same quarter.

Dependent Variable: D(M1)

Method: Least Squares

Sample(adjusted): 279

Included observations: 78 after adjusting endpoints

\begin{tabular}{lclll}
\hline \hline \multicolumn{1}{c}{ Variable } & Coefficient & \multicolumn{1}{c}{ Std. Error } & t-Statistic & \multicolumn{1}{c}{ Prob. } \\
\hline \multicolumn{1}{c}{$\mathrm{C}(\mathrm{G})$} & 3196.405 & 1218.832 & 2.622515 & 0.0106 \\
$\mathrm{D}(\mathrm{I})$ & 0.157787 & 0.046291 & 3.408571 & 0.0011 \\
\hline \hline R-squared & 57.36024 & 84.28319 & 0.680566 & 0.4982 \\
Adjusted R-squared & 0.138674 & Mean dependent var & 3590.628 \\
S.E. of regression & 0.115706 & S.D. dependent var & 11394.58 \\
Sum squared resid & 10715.11 & Akaike info criterion & 21.43440 \\
Log likelihood & $8.61 \mathrm{E}+09$ & Schëarz criterion & 21.52504 \\
Durbin-Ëatson stat & -832.9416 & F-statistic & & 6.037537 \\
\hline \hline
\end{tabular}

The model is:

$D(M 1)=3196.404942+0.1577873032 * D(G)+57.36023856 * D(I)$

The model results significant: addition of $\mathrm{G}$ in a quarter affects the addition of $\mathrm{M} 1$ at the same quarter. This is not for inflation. Absolute change (addition) of $G$ has effect on the addition of M1. The determination degree of $D(M 1)$ from $D(G)$ is statistically important, but at low level.

\subsection{Model prepared to test third hypothesis.}

Dependent Variable: M1

Method: Least Squares

Sample(adjusted): 179

Included observations: 79 after adjusting endpoints

\begin{tabular}{|c|c|c|c|c|}
\hline Variable & Coefficient & Std. Error & t-Statistic & Prob. \\
\hline C & -121671.2 & 15068.06 & -8.074777 & 0.0000 \\
\hline G & 1.214055 & 0.039072 & 31.07220 & 0.0000 \\
\hline I & 559.7940 & 111.0049 & 5.042965 & 0.0000 \\
\hline R-squared & 0.927033 & Mean dependent var & & 178624.6 \\
\hline Adjusted R-squared & 0.925113 & S.D. dependent var & & 84214.01 \\
\hline S.E. of regression & 23045.61 & Akaike info criterion & & 22.96557 \\
\hline Sum squared resid & $4.04 \mathrm{E}+10$ & Schwarz criterion & & 23.05555 \\
\hline Log likelihood & -904.1401 & F-statistic & & 482.7832 \\
\hline Durbin-Watson stat & 1.794945 & Prob(F-statistic) & & 0.000000 \\
\hline
\end{tabular}


The model:

\section{$M 1=-121671.1985+1.21405522 * G+559.7940312^{*} \mid$}

It is verified that the M1 level on a certain period is significantly depended from the GDP and I level on the same period of time. If GDP increases with $1 \mathrm{ALL}$, with constant Inflation, M1 is expected to grow with 1,2 ALL at the same period. If inflation increases with $1 \%$, it is expected that M1 increases with $559 \mathrm{ALL}$ ar the same period (with constant GDP).

\section{Main Findings}

Money supply defined through monetary aggregates has correlations with macroeconomic indicators such as Gross Domestic Product (GDP) and inflation measured with Consumer Price Index.

The economic development requires funds continuously helped from banking system intermediation. Steady GDP increase is achieved with financial stability and slight price changes.

The coordination of politics starts from the phase of drafting the financial programming. In this context money as the most important payments instrument has as an anchor the monetary programming prepared from the Bank of Albania.

Price stability objective requires that daily activities of the central bank should be oriented from operational objectives that have impact on financial system liquidity.

The use of statistical data and econometric models realized with these data, verifies which is the strongest correlation among the indicators that could be employed on forecasting models that could serve to the Bank of Albania.

The verification of hypothesis of the econometric models has interpreted the degree of correlation verified and tested for variables.

The first hypothesis tries to verify that relative changes of M1, M2 and M3 are depended from the relative changes of GDP (G) and Inflation (I). M1 model is verified from basic tests with significant importance of the probability less then $0,05.93 \%$ of the variance in relative change of $M 1$ is defined from relative change of $G$ and I. in this model each \% increase of $\mathrm{G}$ gives $1,4 \%$ increase on $\mathrm{M} 1$, while for $1 \%$ increase of inflation, $\mathrm{M} 1$ increases by $0,5 \%$.

M3 model is statistically accepted with explanation on variance of $95 \%$ where relative changes of M3 are defined from the relative change of $\mathrm{G}$ and $\mathrm{I}$. In this model is verified $1,9 \%$ increase on $\mathrm{M} 3$ for every $1 \%$ increase in $\mathrm{G}$, while $1 \%$ increase of Inflation is transmitted with $0,33 \%$ increase on M3.

With these tests are verified our first hypotheses.

The second hypothesis raised on absolute changes of M1, M2 and M3 that are depended from absolute changes of $G$ and I. Several tests made show that absolute change of M2 and M3 are not proved from changes of $G$ and I in the same quarter. For this reason is employed a model that verifies the impact of $G$ from the previous one, two and three quarters.

The model seems to transmit the problems with the quality of GDP reporting and even with no strong correlation (koef $\mathrm{R}^{2}=0,47$ ) it is proved as significant model.

The third hypothesis, absolute level of aggregates in a quarter, are depended from the level of GDP of the same period, and also from the GDP level one and two periods before, as well as inflation one period before. There is a correlative relation of the fist level on $\mathrm{M} 1$ of this quarter with $\mathrm{M} 1$ of previous quarter and Inflation on the same quarter. If the GDP increases with $1 \mathrm{ALL}$ this quarter, M1 increases by 1,2 ALL the same quarter. If Inflation increases with $1 \%$ on quarter, it is expected that M1 increases by 559 monetary units the same quarter (with constant GDP).

The models realized for the correlations of M1 from GDP and Inflation, and also for M1 one quarter before prove to be significant hypothesis is accepted with $99 \%$ of the variance that explains the factors included in the model.

The Bank of Albania in its activity is working to achieve main objective given as price stability. It manages liquidity in the banking system considering not only transmission mechanism, but also the financial stability of the banking system. Regular reports are given to the Parliament and to the public for the efforts and evaluations organized on the basis of test stress analysis. A continuous coordination with the banking system, other institutions and public transparency works on maintaining stable situation in our banking system.

Banking system could be working on normal time for an economy, but crises and difficult situations are taken into consideration as these could harm the financial stability of every banking system. There are several indicators that are used in stress tests and scenarios can be employed with the changes: on foreign exchange rates, on foreign exchange open positions, on interest rates or other factors that influence results of banking performance and reduce the capital levels. 
The financial stability of Albanian banking system is analyzed in this dissertation using a regression model with independent variables such as: level of credit to economy (KRE) of the previous quarter, real exchange rate (KR) and Gross Domestic Product (GDP) of previous two quarters. The model counts their impact on the Non Performing Loans (NPL) given as dependent variable. The results of the model show that $1 \%$ increase on the exchange rate of a quarter have an impact of $5,66 \%$ on the NPL of next quarter. Also $1 \%$ increase on the lending to economy (measured as loans to GDP) have an impact of 3,82\% increase on Nonperforming Loans.

The results of scenarios show that for the worst historical levels where the lending and GDP are at their minimum level, Nonperforming Loans could be increased by 194,6\%.

This shows that Albanian economy cannot afford difficult situations, where banking system stability seems to be in trouble with big problems in financial intermediation.

\section{Recommendations}

Policy making process in Albania should be organized from a joint- committee with the active participation of main institurion that draft, project and exercise fiskal, monetary and economic policies.

Econometric analysis of monetary and macroeconomic indicators must be an alternativ instrument for the Bank of Albania aiming the achievement of its main objectives.

Econometric models are a powerfull instrument which verifies the level of resistance for Albanian banking system. Different factors can influence the stress level on banking system, but recently non-performing loans and problems of Greek economy are becoming an obstacle to the economic recovery and credit demand.

The Albanian banking system should resolve non-performing loans without the government intervention. Private banks have capacities and sufficient collateral to have a solution.

\section{References}

Macroeconomic Accounting and Analysis in Transition Economies, IMF Institute 1997

Financial Programming and Policy: The case of Turkey, IMF Institute,

Monetary Approach to the Balance of Payments, IMF, 1997

Bank of Albania, (2005). "Preconditions for inflation targeting in Albania", Bank of Albania Open Forum.

Bolle, M., Meyer, T., (2005). "The effectiveness of Monetary Policy in Albania and the need for further reforms", Central banking in the time of integration, pp. 19-52.

Estrella, A., Mishkin, F. S., (1996) "Is there a role for monetary aggregates in the conduct of monetary policy?", NBER Working Paper No 5845.

Çeliku, E., Shtylla, D., Hashorva, G., Hoxholli, R., Kota, V., (2006). "The Portfolio of Econometric Models for Inflation Forecasting at the Bank of Albania: Updated in 2006", Bank of Albania Discussion Paper.

Haderi, S., Kolasi, G., (2003). "Should the Bank of Albania adopt the inflation targeting regime", paper presented at the BoA conference "Albanian economy: performance and policy challenges".

Kalra, S.,(1998)"Inflation and Money Demand in Albania,IMF Working Paper98/101

Kolasi, G., Shijaku, H., Shtylla, D., (2007). "Monetary transmission mechanism in Albania". Bank of Albania Working Paper.

Luci, E., Ibrahimi, F., (2005). "A review of Albanian monetary targeting regime with insights into the future.", Central banking in the time of integration, pp. 193-212.

Luci, E., Vika, I., (2005). "The credit channel in Albania - Evidence from micro data". Bank of Albania Working Paper.

McCallum, B., (1989). "Targets, Indicators and Instruments of Monetary Policy". NBER Working Paper N0 3047.

Muço, M., Sanfey, P., Taçi, A., (2003)."Inflation, exchange rates and the role ofmonetary policy in Albania". Paper presented at the Fourth International Conference: "Albanian Economy, Performance and Policy Challenges.", 2003.

Peeters, M., (2005)."What about Monetary Transmission in Albania? Is theExchange Rate Pass-Through (still) the Main Channel?", 'Central banking in the time of integration' Bank of Albania.

"Preconditions for Inflation Targeting", (2006).Bank of Albania, proceedings of the Open Forum "Preconditions for Inflation Targeting in Albania" held in Tirana, Albania, 1-2 December

Themeli, E., Kolasi, G., (2006). The IT case in Albania -A tentative road-map for implementing IT in Albania. Round Table - Inflation Targeting 2. pp. 15-37.

Osmani, Myslym,(2010). Ekonometri (me zbatime). Tiranë. 